\title{
Útflutningur hráefna: Hagræn áhrif
}

\author{
Ragnar Árnason ${ }^{1}$
}

\begin{abstract}
Ágrip
Ein af meginniðurstöðum hagfræðinnar er að óheft alpjóðaviðskipti bæti nýtingu framleiðslupátta og auki heimsframleiðslu. Með vísan til hennar hefur verið lögð á pað nokkur áhersla í efnahagsskipulagi heimsins að gera milliríkjaviðskipti sem frjálsust.

Frjáls milliríkjaviðskipti krefjast pess að pjóđir sem búa yfir verðmætum hráefnum svo sem jarðefnum, orkulindum eða fiskistofnum selji pessi hráefni hæstbjóðanda. Sá er oft staðsettur erlendis par sem iðnvæðing er hápróuð og markaðir stórir. Heimaríkið verður pví iðulega útflutningsland hráefna, en úrvinnsla peirra fer fram erlendis.

Í pessari grein verður reynt að varpa ljósi á ýmsar hagrænar hliðar á útflutningi hráefna. Nánar tiltekið verður leitað svara við eftirtöldum spurningum: Er útflutningur hráefna til pess fallin að auka landsframleiðslu í útflutningslandinu? Sé svo munu pá allir hagnast? Mun útflutningslandið eflast á aðra mælikvarða, t.d. fólksfjölda? Eykur svona útflutningur heimsframleiðsluna?

Niðurstöðurnar eru í megindráttum að óheft alpjóðaviðskipti leiði til pess að samanlögð landsframleiðsla útflutningslands og innflutningslands vaxi, en vera kunni að landsframleiðsla í útflutningslandi hráefna lækki og fólki fækki. Seljendur hráefnanna muni á hinn bóginn ávallt hagnast.
\end{abstract}

\section{Abstract}

One of the main findings of economic theory is that unhampered international trade will improve allocation of resources and increase overall production. On the basis of this finding, nations of the world have cooperated in global efforts to remove trade barriers and render international trade as free as possible.

Free international trade demands that nations that hold valuable raw materials such as minerals, energy sources or fish stocks make them available to the highest bidder. This bidder is often located abroad where industrialization is highly advanced and large markets readily accessible. As a result the home country may assume the role of a raw material exporter while the processing and marketing of the final products takes place abroad.

This paper attempts to elucidate certain economic aspects of the export of raw materials. More precisely, answers to the following questions will be sought: Is the export of raw materials likely to increase the net domestic product of the export country? If so, will all domestic groups benefit? Will the raw material exporting country be strengthened in terms of other measures such as population? Will the free export of raw materials increase the net global product?

It is found that unhindered international trade will generally increase the combined net national product of the export and import country. However, it is possi-

1 Ragnar Arnason er professor emeritus við Háskóla Íslands. Netfang: ragnara@hi.is

This work is licensed under a Creative Commons Attribution 4.0 License.

DOI: https://doi.org/10.24122/tve.a.2020.17.1.5

(C) Tímarit um viðskipti og efnahagsmál

www.efnahagsmal.is 
ble that export of raw materials will reduce the net domestic product and reduce the population of the exporting country.

JEL flokkun: F1, F11, F43, F63

Lykilorð: Milliríkjaviðskipti, ábati af milliríkjaviðskiptum, útflutningur hráefna, alpjoðleg viðskiptastefna

Keywords: International trade, benefits of free international trade, export of raw materials, international trade policy

\section{Export of Raw Materials: Economic impacts}

\section{Inngangur}

Mörg lönd vinna hráefni og flytja pau út í stað pess að vinna frekar úr peim innanlands. Bættar samgöngur og lækkun annarra viðskiptahindrana hafa stundum leitt til pess að hráefni sem áđur voru fullunnin innanlands eru flutt út tiltölulega óunnin. Á petta ekki hvað síst, en alls ekki eingöngu, við um svokölluð próunarlönd. Vekur petta spurningar um hagkvæmni svona útflutnings.

Í pessari grein verður reynt að varpa ljósi á ýmsar hagrænar hliðar á útflutningi hráefna. Nánar tiltekið verður leitað svara við eftirtöldum spurningum: Er útflutningur hráefna til pess fallin að auka landsframleiðslu í útflutningslandinu? Sé svo munu pá allir hagnast? Mun útflutningslandið eflast á aðra mælikvarða, t.d. fólksfjölda? Eykur svona útflutningur heimsframleiðsluna?

Til pess að leita svara við pessum spurningum verður stuðst við einfalt líkan af framleiðslu og útflutningi hráefna sem er bæði nægilega öflugt til að svara ofangreindum spurningum og í viðunandi samræmi við hagrænan raunveruleika

Раð er ein af meginniðurstöðum hagfræðinnar að óheft alpjóðaviðskipti séu til pess fallin að bæta nýtingu framleiðslupátta og auki heimsframleiðslu (sjá t.d. Ricardo, 1817, Kindleberger, 1962 og Maier, 1980). Pessa niðurstöðu má kalla meginreglu alpjóðaviðskipta. Með vísan til hennar hefur verið lögð á pað nokkur áhersla í heimsskipulaginu að gera milliríkjaviðskipti sem frjálsust.

Ástæða er til að vekja athygli á pví að ofangreind meginregla alpjóðaviðskipta segir ekkert um áhrif milliríkjaviðskipta á landsframleiðslu og efnahagspróun í hvoru viðskiptalandi fyrir sig. Sú ályktun sem oft er dregin af kenningum hagfræðinnar um milliríkjaviðskipti að bæði löndin hljóti að hagnast á slíkum viðskiptunum krefst veigamikilla viðbótarforsendna. Á meðal peirra forsendna má nefna að (i) ákvörðun um útflutning sé tekin frá sjónarmiði pjóðarhags og (ii) vinnuafl og fjármunir flytjist ekki milli landanna. Bregðist önnur eða báðar af pessum forsendum er alls ekki víst að hagur beggja landanna vænkist (sjá t.d. Samuelson, 1962 og 2004 og Schumacher, 2013). ${ }^{2}$

Meginregla alpjóðaviðskipta segir heldur ekkert um áhrif milliríkjaviðskipta á hag tiltekinna landsvæða eða félagshópa innan viðkomandi landa. ${ }^{3}$ Pví síður svarar hún spurningum um hvort útflutningur hráefna eða fullvinnsla peirra innanlands sé ráđlegri efnahagsstefna pegar til lengdar lætur. Prátt fyrir að svör við pess um spurningum hafi augljóst gildi fyrir efnahagsstjórn og hagpróun í einstökum löndum virðast hagfræðingar ekki hafa sýnt peim mikinn áhuga. A.m.k. hefur mér ekki tekist prátt fyrir nokkra leit að finna frambærilega hagræna greiningu sem svarar pessum spurningum. Félagsfræðingar hafa af einhverjum ástæðum sýnt pessu málefni meiri áhuga. Rannsóknir peirra á efnahags-

2 คað er t.d. auðvelt að ímynda sér dæmi um að opnun fyrir viðskipti við önnur svæði leiði beinlínis til hruns heimaframleiðslunnar vegna brottflutnings vinnuafls og fjármagns. Ýmis svokölluð byggðavandamál bæði á Íslandi og í öðrum löndum eru glögg dæmi um petta.

3 Jafnvel pótt landsframleiðsla aukist í kjölfar útflutnings er ekki par með sagt að hagur allra á landsvæðinu batni og raunar auðvelt að ímynda sér dæmi um hið gagnstæða. 
próun pjóðríkja benda til pess að útflutningur hráefna geti unnið gegn hagvexti í útflutningslandinu (sjá t.d. Delacroix, 1977, Stokes og Jaffe, 1982). Fær sú empíríska niðurstaða nokkurn stuðning í niðurstöðum pessarar greinar.

\section{Líkan}

Hugleiðið hagkerfi með tvo tengda atvinnuvegi. Atvinnuvegur 1 er hráefnisvinnsla. Atvinnuvegur 2 er úrvinnsla. Aðrir atvinnuvegir geta verið í hagkerfinu. Til að auðvelda sýn á aðalatriði pessarar greinar gerum við í upphafi ráð fyrir að framleiðsla peirra sé föst. Síðar í greininni (kafla 4) verður slakað á peirri forsendu.

Látum $Y 1$ vera virðisauka í atvinnuvegi 1 og $Y 2$ virðisauka í atvinnuvegi 2. Látum jafnframt vinnuaflspörf í atvinnuvegi 1 vera $a \cdot Y 1$ og $b \cdot Y 2$ í atvinnuvegi 2, par sem $a$ og $b$ eru fastar.

Látum einingarverð vinnuafls vera $w$. Til að einfalda greininguna gerum við í upphafi ráð fyrir að $w$ sé fasti. Раð gæti verið af ýmsum ástæðum. Ein er að vinnuafl geti flutt sig kostnaðarlaust milli landa og $w$ ákvarðist par með á alpjóðlegum vinnumarkaði.

Gerum nú ráð fyrir að í stað pess að vinna hráefnið innanlands sé unnt að flytja pað út fyrir upphæðina $P .{ }^{4}$ Við táknum hlutfall útflutts hráefnismagns með $\alpha$ par sem $\alpha \in[0,1]$. $\alpha=0$ merkir að ekkert hráefni sé flutt út og $\alpha=1$ að pað sé allt flutt út.

Hrein landsframleiðsla, $n d p$, mælir pau verðmæti sem framleidd eru á landsvæðinu og unnt er að ráđstafa til neyslu eða fjárfestingar. Samkvæmt skýrgreiningu er hrein landsframleiðsla summa vinnulauna og hreins hagnaðar 5 .

$$
n d p=\text { vinnulaun+hagnaður } \equiv v+\pi \text {. }
$$

Samkvæmt ofansögðu eru vinnulaun:

$$
v=w \cdot a \cdot Y 1+w \cdot b \cdot(1-\alpha) \cdot Y 2
$$

Hagnaður er hins vegar virðisauki að frádregnum launum, p.e.

$$
\begin{aligned}
& \pi=Y 1+(1-\alpha) Y 2+\alpha \cdot P-v= \\
& Y 1 \cdot(1-a \cdot w)+(1-\alpha) \cdot Y 2 \cdot(1-b \cdot w)+\alpha \cdot P
\end{aligned}
$$

Samkvæmt (1) til (3) má pví rita hreina landsframleiðsla sem:

$$
n d p=\Upsilon 1+(1-\alpha) \cdot \Upsilon 2+\alpha \cdot P
$$

Takið eftir að vinnulaun, hagnaður og hrein landsframleiðsla eru föll af útflutningshlutfalli hráefna, $\alpha$. Takið jafnframt eftir að sé allt hráefni flutt út, p.e. $\alpha=1$, verður hrein landsframleiðsla:

$$
n d p=Y 1+P
$$

Sé hins vegar ekkert hráefni flutt út er hrein landsframleiðsla:

$$
n d p=Y 1+\Upsilon 2
$$

4 Раð аð unnt sé að flytja hráefnið út fyrir fast verð jafngildir forsendu um að viðkomandi hagkerfi sé smátt miðað við umhverfið.

5 p.e. hagnaðar eftir afskrift fjármuna. 


\section{Greining}

Раð er pjóðhagslegt viðfangsefni að velja pað útflutningshlutfall, $\alpha$, sem hámarkar pau verðmæti sem til ráðstöfunar eru í landinu, p.e. hreina landsframleiðslu. Samkvæmt líkingu (4) má rita petta viðfangsefni formlega sem:

$\operatorname{Hám}_{\alpha} n d p=Y 1+(1-\alpha) \cdot Y 2+\alpha \cdot P$

Auðvelt er að ganga úr skugga um að pessi hámörkun leiðir til eftirfarandi ákvörðunarreglu:

Regla 1 (hámörkun hreinnar landsframleiðslu): $\alpha=1$ ef $P>Y 2$, en $\alpha=0$ að öðrum kosti.

Með öðrum orðum: Allt hráefni skal flutt út ef hreinar tekjur af slíkum útflutningi (p.e. $P$ ) eru umfram virðisauka (summu launa og hagnaðar) í úrvinnslugeiranum. Annars skal ekkert flytja út. ${ }^{6}$

Regla 1 hámarkar hag á viðkomandi landsvæði í peim skilningi að hrein landsframleiðsla (p.e. virðisauki) par er eins há og hún getur orðið. Sé reglu 1 fylgt mun útflutningur hráefnis pví gera pað að verkum að unnt er að bæta hag allra í landinu (svæðinu). Рar með er hins vegar ekki sagt að pað gerist í raun.

Sé ákvörðun um útflutning hins vegar tekinn af fyrirtækjum munu pau að öllum líkindum velja útflutningshlutfallið $\alpha$ pannig að hagnaður peirra sé hámarkaður. Samkvæmt líkingu (3) munu pau pví leitast við að:

$$
\operatorname{Hám}_{\alpha} \pi=Y 1 \cdot(1-a \cdot w)+(1-\alpha) \cdot Y 2 \cdot(1-b \cdot w)+\alpha \cdot P \text {. }
$$

Pessi hámörkun leiðir til ákvörðunarreglunnar:

Regla 2 (hámörkun hagnaðar): $\alpha=1$ ef $P>Y 2 \cdot(1-b \cdot w)$, en $\alpha=0$ að öðrum kosti.

M.ö.o. allt hráefni skal flutt út ef hreinar tekjur af slíkum útflutningi (p.e. $P$ ) eru umfram hagnað í úrvinnslugeiranum.

Augljós munur er á pessum tveimur reglum. Regla 1 hámarkar virðisauka, p.e. summu launa og hagnaðar. Regla 2 hámarkar aðeins hagnað. Afleiðingin er að regla 2 getur leitt til hráefnaútflutnings pótt regla 1 geri pað ekki. Samanburður á reglum 1 og 2 sýnir að petta gerist ef útflutningsvirði hráefna, $P$, er á bilinu frá $Y 2 \cdot(1-b \cdot w)$ til $Y 2$. Petta bil er ekki tómt nema í pví fágæta tilviki að engin laun séu í úrvinnslugeiranum, p.e. $b \cdot w=0$. Рar með hefur verið sýnt fram á eftirfarandi:

Niðurstaða 1. Við pær aðstæður sem lýst er getur óheftur útflutningur (p.e. hámörkun hagnaðar) lækkað hreina landsframleiðslu í útflutningslandinu.

Til frekari útskýringar getur verið gagnlegt að lýsa peim samhengjum sem um ræðir með myndrænum hætti. Er pað gert í mynd 1. Í peirri mynd mælir lárétti ásinn virði útflutnings, $P$. Lóðrétti ásinn mælir hreina landsframleiðslu, $n d p . Y 1$ á peim ási er virðisauki við framleiðslu hráefna og $Y 1+Y 2$ er heildarvirðisauki ef allt hráefnið er unnið innanlands (sjá líkingu $\left.\left(4^{\prime \prime}\right)\right)$. Sé hráefnið hins vegar flutt út er virðisauki af peim útflutningi $P$ og hrein

6 pessi einfalda „bang-bang“ regla stafar auðvitað af pví að markmiðafallið er línulegt í stýribreytunni, $\alpha$. 
landsframleiðsla $n d p=Y 1+P$ samkvæmt líkingu $\left(4^{\prime}\right)$. Graf peirrar líkingar sem fall af $P$ er dregið sem $45^{\circ}$ línan sem hefst í $Y 1$ og er merkt $\alpha=1$ í mynd 1.

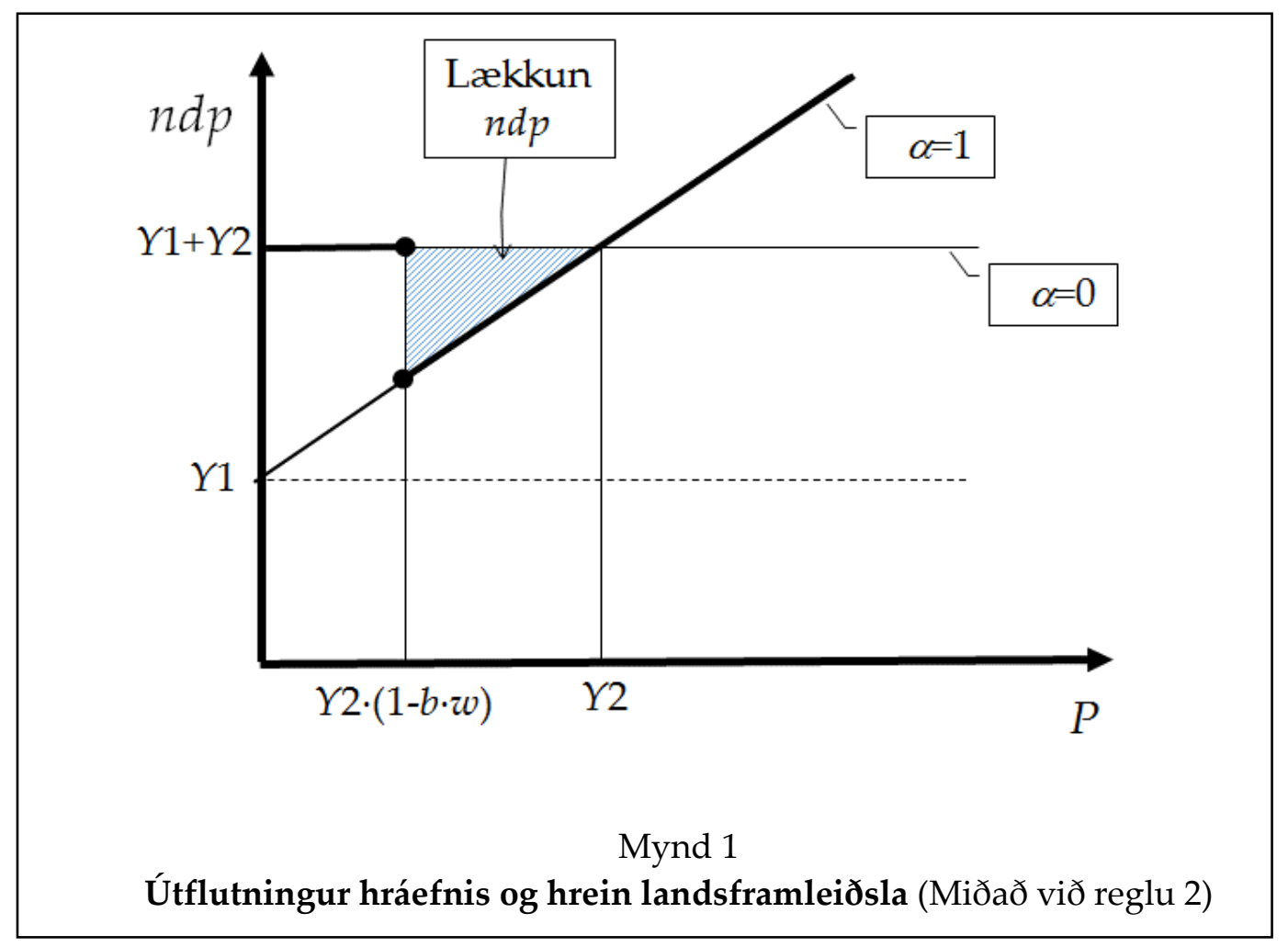

Ljóst er að pótt regla 2 (p.e. hámörkun hagnaðar) ráði mun útflutningur hráefna ekki eiga sér stað ef verð útflutningsins, $P$, er minna en $Y 2 \cdot(1-b \cdot w)$. Slíkur útflutningur myndi einfaldlega minnka hreinan hagnað fyrirtækjanna. Hrein landsframleiðsla upp að pessu útflutningsverði er pví $Y 1+Y 2$ og táknað með breiðu láréttu línunni í mynd 1. Sé útflutningsverðið hærra en $Y 2 \cdot(1-b \cdot w)$ geta fyrirtækin aukið hagnað með pví að hætta úrvinnslu og flytja hráefnið út. Samkvæmt reglu 2 mun pað pví verða gert. Рað leiðir til hreinnar landsframleiðslu sem lýst er með feitletraða hluta $\left(45^{\circ}\right)$ línunnar sem merkt er $\alpha=1$. Eins og mynd 1 sýnir mun slíkur útflutningur lækka hreina landsframleiðslu, ndp, nema útflutningsverðið, $P$, sé nægilega hátt. Sé útflutningsverðið t.d. rétt yfir hagnaði af úrvinnslu innanlands, p.e. $Y 2 \cdot(1-b \cdot w)$, munu fyrirtækin flytja hráefnið út, en hrein landsframleiðsla lækka verulega eins og mynd 1 sýnir. Sé útflutningsverðið umfram Y2 sé mun útflutningur hráefnis hins vegar hækka $n d p$ og reglur 1 og 2 vera sammála.

Rétt er að hafa í huga að pótt útflutningsverðið sé umfram $Y 2$ og útflutningur hækki par með hreina landsframleiðslu er ekki par með sagt að hagur allra landsmanna batni. Sá hluti peirra sem áđur vann í úrvinnslugeiranum hefur nú ekki pá atvinnu lengur og verður pví að leita annars lífsviðurværis. Verði ekki gerðar sérstakar ráđstafanir til að endurskipta útflutningstekjunum er pví ólíklegt að hagur peirra batni.

Niðurstaða 1 kann í fljótu bragði að virðast í ósamræmi við viðteknar skoðanir um hagkvæmni alpjóðaviðskipta sem raktar voru í inngangi. Svo er pó ekki. Munið að meginregla alpjóðaviðskipta fjallar aðeins um heildarhagkvæmni en segir ekkert um viðkomandi pjóðlönd eða einstaka félagshópa innan peirra.

Til að sjá að líkan pað af milliríkjaviðskiptum sem notast var við hér að ofan er í fullu samræmi við meginreglu alpjóðaviðskipta skulum við íhuga áhrif útflutnings hráefna á hreina landsframleiðslu í heild, p.e. samanlagða landsframleiðslu útflutnings- og innflutningslands. Pessa heildarlandsframleiðslu má rita sem hér segir: 


$$
N D P \equiv n d p_{1}+n d p_{2}=\Upsilon 1+(1-\alpha) \cdot Y 2+\alpha \cdot P+\alpha \cdot w \cdot b \cdot Y 2
$$

par sem $n d p_{1}$ er hrein landsframleiðsla útflutningslands og $n d p_{2}$ hrein landsframleiðsla innflutningslands. Síðasti liðurinn í seinni jöfnunni, $\alpha \cdot w \cdot b \cdot Y 2$, eru viðbótarlaun í innflutningslandinu vegna aukinnar úrvinnslu í magninu $\alpha \cdot Y 2$. Takið eftir að í líkingu (5) höfum við gert ráð fyrir að vinnuaflspörf við úrvinnslu hráefnis í innflutningslandinu sé sú sama og í útflutningslandinu og að $P$, p.e. útflutningsvirði hráefnisins, sé nákvæmlega sama og hagnaðurinn af pví að vinna pað par. Hins vegar er auðvitað ekki ólíklegt að sá hagnaður sé hærri en verðið en í núverandi samhengi breytir pað engu sem máli skiptir. ${ }^{7}$

Auðvelt er að ganga úr skugga um að hámörkun heildarlandsframleiðslu landanna beggja leiðir til ákvörðunarreglunnar:

Regla 3 (Hámörkun landsframleiðslu í heild): $\alpha=1$ ef $P>Y 2 \cdot(1-b \cdot w)$, en $\alpha=0$ að öðrum kosti.

En petta er nákvæmlega sama reglan og gildir fyrir hámörkun hagnaðar í útflutningslandinu, p.e. regla 2. Petta staðfestir meginreglu alpjóðaviðskipta að frjáls milliríkjaviðskipti hámarki heildarhag viðskiptalandanna.

Niðurstaða 1 sýnir á hinn bóginn að ekki er víst að útflutningslandið hagnist á viðskiptunum. Ástæðan er sú að hrein landsframleiðsla í pví landi getur minnkað.

Nú blasir við að til að unnt sé að vinna úr hinu innflutta hráefni í innflutningslandinu parf meira vinnuafl. Nærtækast er að petta vinnuafl komi frá útflutningslandi hráefnisins par sem pað áður vann við úrvinnslu. Sé pessi flutningur vinnuaflsins kostnaðarlaus er pví ljóst að vinnuaflið í útflutningslandinu tapar engu. Pað tekur sér hins vegar bólfestu í nýju landi. Jafnframt er ljóst að landsframleiðsla í innflutningslandinu hækkar sem nemur vinnulaunum við úrvinnslu, p.e. $w \cdot b \cdot Y 2$. Landsframleiðsla í útflutningslandinu breytist hins vegar sem nemur $P-w \cdot b \cdot Y 2$. Sem fyrr greinir er pessi breyting neikvæð ef $P<w \cdot b \cdot Y 2$ en annars jákvæð.

Við getum dregið ofangreindar niðurstöður saman í eftirfarandi töflu:

Tafla 1 Áhrif hráefnisútflutnings: Samandregnar niðurstöður

\begin{tabular}{lccc}
\hline & Útflutningsland & Innflutningsland & Samanlagt \\
\hline Landsframleiðsla & $-/+$ & + & + \\
\hline Hagnaður & + & $0 /+$ & + \\
\hline Atvinnutekjur & - & + & 0 \\
\hline Hagnaður/atvinnutekjur & + & $?$ & + \\
\hline Mannfjöldi & - & + & 0 \\
\hline
\end{tabular}

Táknmál: + hækkun; - lækkun; 0 engin breyting; a/b táknar a eða b

Eins og sjá má í töflu 1, eykst samanlögð landsframleiðsla viðskiptalandanna við útflutning hráefna (enda er hann frjáls). Er pað í samræmi við meginreglu alpjóðaviðskipta. Takið eftir að hagnaður eykst einnig (annars myndu viðskiptin ekki eiga sér stað), en atvinnutekjur ekki. Pví hækkar hlutfall hagnaðar af samanlagðri landsframleiðslu.

Tafla 1 sýnir einnig að hvað landsframleiðslu, hagnað, atvinnutekjur og mannfjölda

7 Par sem útflutningsfyrirtækin hljóta ekki pann hagnað breytir hann engu um ákvörðun peirra um útflutning eða ekki. Sé P á hinn bóginn ekki nægilega hátt til að fá pau til að flytja út en innflutningur hráefna myndi skila hagnaði í innflutningslandinu myndi P hækka vegna eftirspurnarinnar í innflutningslandinu. 
snertir eru áhrifin nánast einvörðungu upp á við í innflutningslandi hráefna. Öðru máli gegnir um útflutningslandið. Par fara atvinnutekjur og mannfjöldi niður á við og e.t.v. landsframleiðsla einnig. Hagnaður fyrirtækja hækkar hins vegar, enda myndu pau ekki flytja út hráefni sitt nema svo væri. Í útflutningslandinu hækkar pví hlutdeild hagnaðar í landsframleiðslunni..

Rétt er að vekja athygli á pví að pótt landsframleiðsla í útflutningslandinu kunni að hækka er ekki víst að pjóðartekjur geri pað. Sem fyrr er rakið hækkar landsframleiðslan ef verðmæti útflutnings er umfram virðisauka af fullvinnslu innanlands. Með pví að útflutningur hráefnisins krefst væntanlega mun minni umsjónar en fullvinnsla er spurning hvort útflytjendurnir kjósa að búa áfram í útflutningslandinu eða flytja búsetu sína til innflutningslandsins par sem peir gætu t.d. litið eftir fullvinnslunni par. Ef peir taka síðari kostinn verður $P$ hluti af pjóðarframleiðslu innflutningslandsins og pjóðarframleiðsla í útflutningslandinu minnkar sem nemur $Y 2$, jafnvel pótt landsframleiðslan breytist aðeins um $P-Y 2$.

Spyrja má hví vinnuaflið innanlands geti ekki einfaldlega boðið úrvinnslugeiranum að lækka launin til að halda úrvinnslunni í landinu? Fyrir pví geta verið ýmsar ástæður. Í fyrsta lagi myndi vinnuaflið ekki vilja bjóða slíkt ef pað getur flutt sig kostnaðarlaust til innflutningslandsins. Pessi kostur kemur með öðru orðum ekki til álita nema vinnuaflið sé ekki fyllilega hreyfanlegt. Í öðru lagi er hugsanlegt að kjarasamningar og sterk verkalýðshreyfing komi í veg fyrir slíkan sveigjanleika í launum. Í priðja lagi er rétt að hafa í huga að vinnuaflið er yfirleitt ekki haft með í ráðum pegar eigendur fyrirtækja eru að ráðstafa hráefnum sínum. Рað er pví síður en svo sjálfgefið að pví gefist kostur á að gera eigendunum svona tilboð. Í fjórða lagi er alls ekki víst að launalækkun dugi til að halda úrvinnslunni í landinu. Рað er nefnilega vel hugsanlegt að útflutningsvirðið, p.e. $P$, sé hærra en samanlagður virðisauki af úrvinnslunni innanlands.

\section{Aðrir atvinnumöguleikar innanlands}

Hér að framan hefur verið gert ráð fyrir að vinnuafl í úrvinnsluiðnaðnum geti ekki fundið aðra atvinnu innanlands og verði pví annað hvort atvinnulaust eða vinni við úrvinnsluna erlendis. Öllu raunsærra er að einhverjir atvinnumöguleikar séu innanlands, pótt launin séu að öllum líkindum lægri. Til pess að vinnuaflið taki atvinnu innanlands á lægri launum er auðvitað nauðsynlegt að pví fylgi kostnaður að flytja til útlanda til að fá alpjóðlegu launin $w$.

Gerum ráð fyrir að vinnuaflið í úrvinnsluiðnaðnum geti fundið störf í öðrum atvinnugreinum innanlands á launum w’ og kjósi að taka pau laun. Sé svo er hrein landsframleiðsla í útflutningslandinu:

$$
n d p=\Upsilon 1+(1-\alpha) \cdot Y 2+\alpha \cdot P+\alpha \cdot b \cdot Y 2 \cdot w^{\prime}
$$

Takið eftir að líking (4) er sértilfelli af líkingu (6) par sem $w^{\prime}=0$.

Hámörkun hreinnar landsframleiðslu samkvæmt (6) leiðir til eftirfarandi lagfæringar á reglu 1:

Regla 1' (hámörkun $n d p)$. $\alpha=1$ ef $P>Y 2 \cdot\left(1-b \cdot w^{\prime}\right)$, en $\alpha=0$ að öðrum kosti.

Takið eftir að í pví sértilviki að $w^{\prime}=0$, verður regla 1' eins og regla 1, en í hinu sértilvikinu að $w^{\prime}=w$, p.e. jafngóð laun í boði í öðrum atvinnuvegum innanlands verður regla 1' eins og regla 2. Petta endurspeglar að líking (6) fyrir hreina landsframleiðslu er almennari en líking (4).

Möguleikar á annarri atvinnu innanlands hækkar virðisauka af útflutningi hráefnis frá $P$ yfir í $P+b \cdot Y 2 w^{\prime}$. Par með verður hrein landsframleiðsla ef hráefnið er allt flutt út hærri en 
áður eða $n d p=Y 1+P+b \cdot Y 2 w^{\prime}$. Petta hækkar hallatölu útflutningslínunnar ( $\left.\alpha=1\right)$ í líkingu við pað sem lýst er í mynd 2. Möguleg lækkun $n d p$ vegna útflutnings er að sama skapi minni. Ef t.d. $w^{\prime}=w$ fer útflutningslínan í gegn um hnitið $(Y 2 \cdot(1-b \cdot w), Y 1+Y 2)$ og lækkun landsframleiðslu vegna útflutnings er engin.

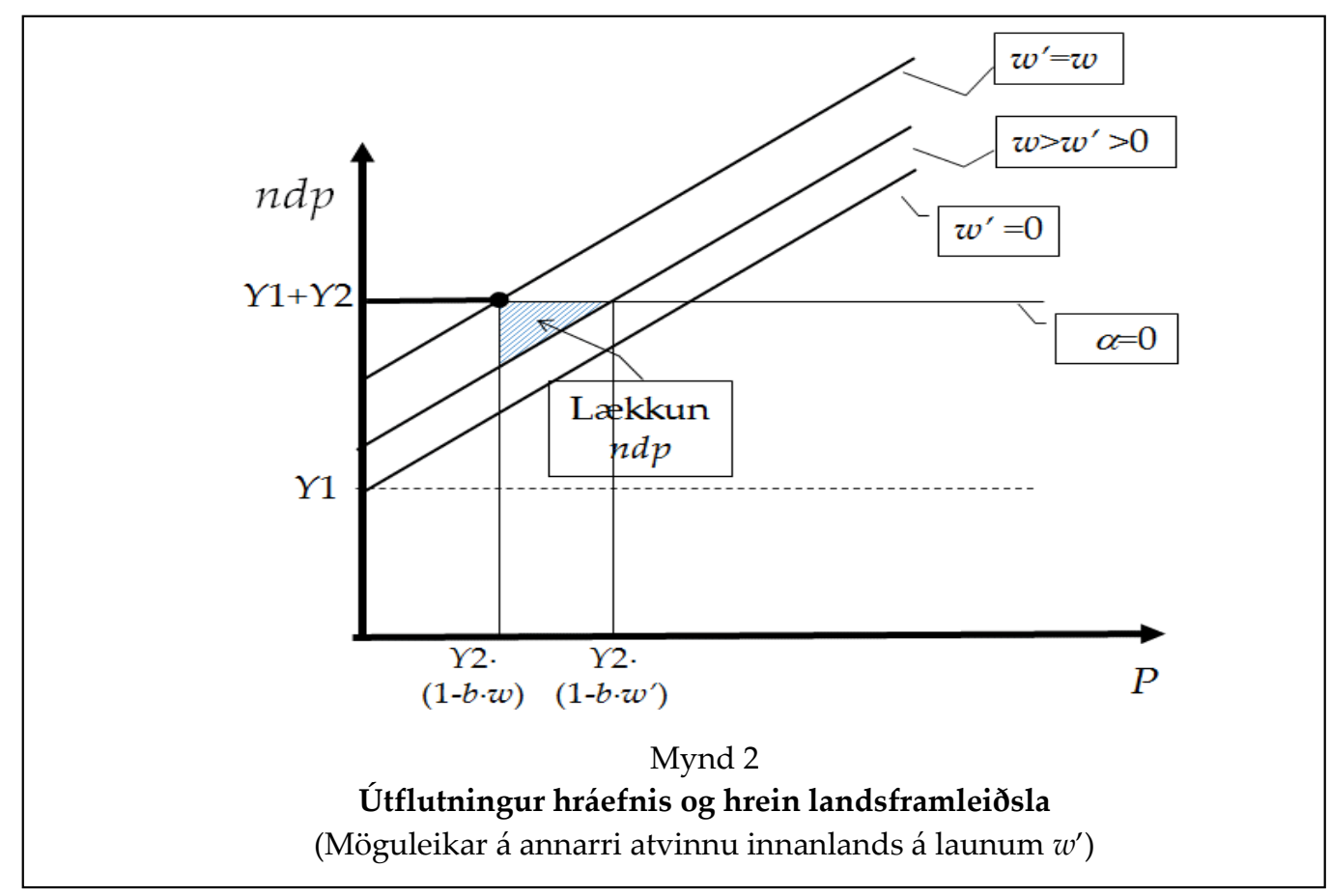

Af pessu getum við dregið eftirfarandi ályktun: Eftir pví sem vinnuaflið sem áður vann í úrvinnslugreininni getur fengið hærri laun við önnur störf innanlands peim mun minni verður möguleg lækkun hreinnar landsframleiðslu í kjölfar útflutnings hráefnisins. Hins vegar er rétt að minna á pað að vinnuaflið mun ekki taka lægri laun innanlands nema kostnaður við af sækja hærri laun á alpjóðlegum markaði sé umfram launamuninn.

\section{Lokaord}

Ljóst er að séu milliríkjaviðskipti á annað borð möguleg og útflutningsverð hráefnanna umfram pann hagnað sem unnt er að hafa af vinnslu peirra innanlands munu eigendur fyrirtækja kjósa að flytja hráefni út fremur en að vinna pau innanlands. Greiningin hér að framan sýnir að slíkur útflutningur hráefna getur bæði aukið og minnkað hreina landsframleiðslu í útflutningslandinu. Hrein landsframleiðsla minnkar ef útflutningsverð hráefnanna er lægra en virðisaukinn (p.e. summa launa og hagnaðar) af úrvinnslu peirra innanlands og vinnuaflið sem áður vann í úrvinnslugeiranum fær ekki jafnhá laun við aðra vinnu innanlands. Hrein landsframleiðsla vex hins vegar ef útflutningsverð hráefnanna er hærra en heildarvirðisaukinn í úrvinnslu peirra innanlands.

Hvort útflutningur hráefna er ráðleg stefna fyrir útflutningslandið er pví mjög háð pví hvert útflutningsverðið er (miðað við virðisaukann við úrvinnslu innanlands) og hvort vinnuaflið sem áður vann í úrvinnslugeiranum fær jafngóð laun við önnur störf innanlands. Petta segir hins vegar ekki nema hluta af sögunni.

Jafnvel pótt útflutningsverð hráefna sé nægilega hátt til að hrein landsframleiðsla hækki með útflutningi munu vinnuafl og fyrirtæki í úrvinnslugeiranum verða fyrir efnahagslegum skakkaföllum við útflutninginn. Tekjur af útflutningi hráefna (p.e. hinn pjóðhagslegi ábati af útflutningnum) rennur fyrst og fremst í vasa útflytjendanna, a.m.k. í upphafi. Раð er síður en svo víst, og raunar fremur ólíklegt, að pessir útflytjendur séu peir sömu 
og úrvinnsluaðilarnir sem skakkaföllin purfa að bera. Dví er pað að hefjist útflutningur hráefna, t.d. vegna pess að markaðsleið hefur opnast, má gera ráð fyrir að í kjölfarið fylgi viss endurskipting á landsframleiðslunni par sem hagur útflytjenda batnar örugglega en aðilar í úrvinnslugreinum kunna að tapa.

Par eð atvinnutækifæri við úrvinnslu hráefnanna hverfa frá útflutningslandinu en aukast í innflutningslandinu er ekki ólíklegt að vinnuaflið í úrvinnslugreininni fylgi að einhverju leyti hráefnunum og flytji einnig úr landi. Að pví marki sem petta gerist, verður færra fólk í útflutningslandinu en ella hefði orðið og hrein landsframleiðsla að sama skapi minni.

Með pví að atvinnulíf í útflutningslandi hráefna verður fábreyttara í kjölfar útflutningsins en áđur var og sérhæft vinnuafl flytur e.t.v. að einhverju marki úr landi er ekki ólíklegt að fjárfestingartækifæri verði par einnig færri og hagvöxtur minni en ella hefði orðið. Útflutningur hráefna í stað úrvinnslu innanlands getur pví fært viðkomandi land yfir á lægri hagvaxtarferil en ella hefði verið. Rétt er pó að vekja athygli á pví að hér er einungis um möguleika að ræða en alls ekki vissu. Eftir pví sem útflutningsverð hráefna er hærra peim mun meira verður hagnaður útflytjenda. Ef peir ráðstafa pví fé til fjárfestinga innanlands getur hagvöxtur aukist og hrein landsframleiðsla orðið hærri í framtíðinni en ella, jafnvel pótt hún kunni að lækka î upphafi. Að petta gerist er pó undir pví komið að nægilega góð fjárfestingartækifæri séu til staðar innanlands sem aukinheldur hefðu ekki verið nýtt án aukins hagnaðar útflytjenda hráefna.

Í inngangi var pað útskýrt og kallað meginregla alpjóðaviðskipta að óheft viðskipti milli landa séu til pess fallin að bæta nýtingu framleiðslupátta og auka heimsframleiðslu. Niðurstöður pessarar greinar eru í samræmi við pessa meginreglu. Рað er hins vegar veruleg oftúlkun á meginreglu alpjóðaviðskipta að bæði viðskiptalöndin muni ávallt hagnast á slíkum viðskiptum. Engin slík fræðileg niðurstaða er fyrir hendi. Í meginreglu alpjóðaviðskipta felst vissulega að bæði viðskiptalöndin geta hagnast á slíkum viðskiptum. Til pess að svo verði purfa hins vegar ýmis önnur skilyrði að vera fyrir hendi.

Í pessari grein er komist að peirri niðurstöðu að útflutningur hráefna geti hæglega dregið úr hreinni landsframleiðslu. Раð er t.d. líklegt til að gerast ef útflutningsverðið er ekki nægilega hátt til mæta öllum virðisaukanum sem skapast af úrvinnslu hráefnanna innanlands. Fyrirtækin sem ráða hráefnunum munu hins vegar flytja pau út ef útflutningsverðið er umfram hagnaðinn af úrvinnslunni. Í pessari grein er pví grunnástæðan fyrir pví að útflutningur hráefna getur lækkað hreina landsframleiðslu sú að ákvörðun um útflutning sé tekin með tilliti til of sértækra hagsmuna.

\section{Heimildir}

Delacroix, J. (1977). The Export of Raw Materials and Economic Growth: A Cross-National Study. American Sociological Review, 42(5), 795-808.

Kindleberger, C.P. (1962). Foreign Trade and the National Economy. New Haven: Yale University Press.

Meier, G. (1980). International Economics: The Theory and Policy. New York: Oxford University Press.

Ricardo. D. (1817. [1951]). Principles of Political Economy and Taxation. Í P. Sraffa og M. Dobb (ritstjórar) The Works and Correspondence of David Ricardo. Cambridge: Cambridge University Press.

Samuelson, P.A. (1962). The Gains from International Trade Once Again. The Economic Journal, 72, 820-829.

Samuelson, P.A. (2004). Where Ricardo and Mill Rebut and Confirm Arguments of Mainstream Economists Supporting Globalization. Journal of Economic Perspectives, 18(3), 135-46.

Schumacher, R. (2013). Deconstructing the Theory of Comparative Advantage. World Economic Review, 2, 83105

Smith, A. (1776 [1981]). An Inquiry into the Nature and Causes of the Wealth of Nations. Í R.H. Cambell og A.J. Skinner (ritstjórar). Indianapolis: Liberty Fund.

Stokes, R. og Jaffee, D. (1982). Another Look at the Export of Raw Materials and Economic Growth. American Sociological Review, 47(3), 402-407. 
